\title{
A discourse analytical perspective on the professionalization of the performance
} appraisal interview

Dorien Van De Mieroop \& Eveline Vrolix

\begin{abstract}
Over the years, performance appraisal interviews have become increasingly professionalized. This is clearly noticeable in the different rating scales and questionnaires that are distributed among supervisors and employees as a support during the preparatory and interviewing phase of the performance appraisal process, as is also in line with current advice given to practitioners. Using discourse analysis as a methodology to study sequential features and discourse strategies in three performance appraisal interviews, this article zooms in on the effect of such a questionnaire (based on the organization's competencies) on the interview itself. The analyses reveal a nuanced picture, demonstrating on the one hand advantages of these questionnaires such as the use of a well-defined agenda which gives the interview structure. On the other hand, disadvantages such as the inefficient use of expensive institutional time due to lengthy terminological explanations are exposed as well.
\end{abstract}

Keywords: performance appraisal interviews, discourse analysis, interactional approach, turn taking, questionnaires 


\section{INTRODUCTION}

Performance Appraisal can be defined as "a general heading for a variety of activities through which organizations seek to assess employees and develop their competence, enhance performance and distribute rewards" (Fletcher, 2001, p.473). Performance Appraisal in general, and performance appraisal interviews in particular, were once rather basic communication processes, but nowadays institutions and organizations increasingly invest resources in them (Asmuß, 2008, p.408) and this results in a growing professionalization of this genre. More specifically, performance appraisal interviews are interactions between managers and their employees "where the goal of assessing an employee's performance is realized using interactive conventions that resemble those of a therapy or counselling session" (Cameron, 2000, p.15). However, in spite of their acknowledged importance, performance appraisal interviews are met with "trepidation" (Clifton, forthcoming) and there is widespread dissatisfaction with performance appraisal methods (Gordon \& Stewart, 2009, p.474). There are many ways of addressing these problems (for an overview, see e.g. Asmuß, 2008, pp.409412), but this paper follows a discursive approach to the study of institutional interaction as in situ workplace practice (e.g. Asmuß, 2008; Clifton, 2006; 2009; Nielsen, 2009). These studies start from the close observation of naturally-occurring data and follow the socialconstructionist (see e.g. Potter, 1996) premise that "organizations are talk, and talk is organizations" (Clifton, 2006, p.202), meaning that "the institutionality of an interaction is not determined by its setting" (Drew \& Heritage, 1992, p.3), but it is talked into being on a turnby-turn basis and negotiated between the interlocutors in an ad hoc way.

This article follows these social-constructionist principles and zooms in on performance appraisal interviews as a genre, rather than an HR intervention, and it focuses on how these interviews are constructed from one turn to the next. Methodologically, we take a discourse analytical perspective on the data. This means that although we are inspired by conversation 
analysis (CA), which incites researchers to look carefully at actual interaction and thus enables the researcher to provide valuable insights in how everyday workplace activities are accomplished (see Asmuß, 2008 and Clifton, 2006 for an overview of CA-studies in relation to workplace interaction), we adopt a wider, pragmatic approach (see e.g. also Rettinger, 2011; Virkkula-Räisänen, 2010). This means that, as well as analyzing the sequential characteristics of the data, we focus on the use of discourse strategies which have proved to be relevant for the study of institutional interaction, such as the use of pronominal forms to indicate an institutional collectivity (see e.g. Poncini, 2004) or the negotiation of face through the use of hedges, boosters and modal verbs (see e.g. Holmes et al., 1999). The aim of our analyses, then, is to see what we can learn from a close observation of the data, which are audio-taped and meticulously transcribed, so that suggestions to improve workplace interaction as a genre can be made.

In this case, we zoom in on the process of the performance appraisal interview, and more particularly, our research question focuses on how the preparations permeate the actual interview itself and what the effect of this preparatory phase on the interview is. In the literature, much attention is paid to this pre-interviewing phase of performance appraisal and thus we aim to contribute to the ongoing dialogue (see Clifton, forthcoming) between what actually goes on in such interviews, and the normative models and theories that can be found in the advisory literature, also called "stocks of interactional knowledge" (Peräkylä \& Vehviläinen, 2003). So before going into a detailed analysis of our data, we first list the stock of interactional knowledge that is directly related to the preparation of performance appraisal interviews.

In general, it is advised that the interview is prepared by the employee's immediate supervisor and the employee and both parties are usually encouraged to reflect on their own/the other's behavior by for example preparing some topics for discussion and reading the 
report of the previous performance appraisal interview again (Jansen et al., 2004). On the one hand, and as has been emphasized by many authors (see e.g. Kikoski \& Litterer, 1983), the employee's extensive participation in the appraisal process is essential. Broekhuis and Holthuis (2004) for example dedicate an entire book to how employees can prepare their interview and how they can get the most out of it. Also Gordon and Stewart (2009) underline the importance of the pre-interview phase for the employee's involvement, for example by increasing awareness through different organizational media over a several-week period (agenda setting) and by proposing frames which will help produce more meaningful conversations that lead to greater mutual understanding about performance (Gordon \& Stewart, 2009, p. 481), thus clearly pointing at a professionalization of this pre-interview phase.

On the other hand, a similar professionalization is noticeable regarding the tasks of the supervisor in this phase, since he or she is often required to work with standardized assessment forms that evaluate the employees at several different levels (Grote, 2002, p.1). Nevertheless in practice, this description seems too simple. While Gioia, Donnellon and Sims (1989) point out that managers and supervisors tend to have shared prototypical scripts for Performance Appraisal, based on shared understandings and a common cognitive set, there are quite a lot of different approaches available for supervisors. Since the aim of this article is not to evaluate the different approaches as such, but rather to investigate how such an approach - in this case, the use of a questionnaire - is dealt with in the interviews and how this can contribute to the interactional success, or alternatively failure of the interview itself, we now shift our focus to a description of the data under investigation. After this, we move to the analytical part of this paper.

\section{THE DATA ${ }^{\mathrm{i}}$}




\section{Data description}

Our data consist of three performance appraisal interviews and an ethnographic interview with the interviewer that we audiotaped in the winter (December - January) of 2010/2011 in a Dutch medical lab. This lab is part of a hospital that was at that point merging with another hospital in the Netherlands. Since the profitability of the hospital is a big issue in this merger and since the lab is under much pressure to be economically profitable, the management of the lab resembles that of many other cost-effective organizations.

The appraisal interviews were all carried out by the same interviewer, a 45-year old woman who is the head of one of the divisions of the lab and who has been working in the lab for 20 years. All the interviewees are trained chemical analysts but they have different hierarchical positions in the lab, namely either level 3, level 2 or level 1-analysts, (thus representing respectively the lower, middle and upper category of the staff), between which the major differences are the additional managerial and administrative tasks of the level 1analysts and the lack of any particular specialization of level 3-analysts. Table 1 gives an overview of the different interviews, which were all characterized by an informal atmosphere, as is also reflected in the consistent use of the local, southern-Dutch dialect.

\section{*** INSERT TABLE 1 ABOUT HERE***}

These interviews were transcribed following the main guidelines of the Jeffersonian transcription system. However, in order to enhance the readability of the fragments, we also integrated standard punctuation (e.g. capitals, full stops, and commas). The interviews were then translated into English. Importantly, in this translation, we tried to keep as close as possible to the original so that the sequential aspects of the interaction, that would be lost in a less literal translation, were retained. This may sometimes result in non-standard grammar and word order which can make the transcripts a bit difficult to follow. 
Complementary to these data, one of the authors interviewed the supervisor in an ethnographic interview that focused on her views and experiences concerning performance appraisals interviews within the lab. Since the focus of this article is on the actual performance appraisal interviews themselves, this ethnographic interview is only implicitly represented in this article and it was used by the authors as background information that led to a correct and more in-depth understanding of the data.

\section{Performance appraisal interviews at the organisation under study}

In this section, we aim to set the stage with an ethnographic overview of the performance appraisal interviews in this organization. This is important, since both the way in which these interviews take place and their impact on the organization, influences how the interlocutors behave and what they aim to achieve during these interactions. We subdivided this section further into the three consecutive stages of the performance appraisal interviews, namely the pre-interviewing phase, the interview itself and the post-interviewing phase.

\section{The pre-interviewing phase}

In this organization, at least once a year, the supervisors are required to organize a performance appraisal interview with their subordinates. The pre-interviewing phase is particularly important in this process since it determines the topics that are to be addressed in the interview. In general, this discussion is based on the four competencies of the organization, namely:

1. self-development;

2. collaborating process consciously ${ }^{\mathrm{ii}}$;

3. result-orientedness; 


\section{4. customer-orientedness.}

These four basic competencies are divided into 23 sub-competencies such as creativity, sensitivity, flexibility, integrity and discipline. All these competencies are translated into a list of very specific topics and questions which is adapted to each specific employee. Next, the supervisors inform their employees about the exact date, time and place of the performance appraisal interview and the topics and questions that will be discussed. An example of such a list of topics and questions as sent to the employees can be seen in appendix 1 .

The employees then prepare their performance appraisal interview on the basis of these topics and questions and they have to send their preparations back to the supervisor prior to the interview. So the interviewees are explicitly invited to prepare the interview in great detail and, as the interviewer indicated during the ethnographic interview, with the exception of one employee out of the 77 employees of the lab, all the interviewees were very well prepared. Thus we can conclude that this organization deals with the preparations of the performance appraisal interviews in a very professional and well-structured way.

\section{The interview itself}

The performance appraisal interviews usually take place in separate rooms located in the laboratory. These rooms are relatively small and sound-proof. No one is allowed to interrupt or disturb the performance appraisal interview once it is underway. Both interviewer and interviewee switch off their mobile phones. The interview itself always starts with greetings and a discussion of how long it has been since the last performance appraisal interview and sometimes also of immediately preceding events in the lab. During the interview, the interlocutors each have their own preparations of the performance appraisal interview in front of them. The interviewer also takes the preparations of the interviewee with her and sometimes refers to these preparations during the interaction. However, depending on the 
interviewee, these preparations and the questionnaires are sometimes adapted by the interviewer in the course of the interview. The interviewer reported that the extent of any adaptation depends mainly on the personality of the interviewee, his or her personal situation, the presence of personal and/or professional problems and the reports of previous interviews with the employee.

\section{The post-interviewing phase}

The consequentiality of the performance appraisal interviews seems relatively limited in this organization since they are not directly related to pay or promotion to a higher level. Opportunities for promotion are always openly communicated to all the employees and result in official vacancies for which all employees can apply. Of course, the way in which a specific employee functions in the organisation is taken into account in this promotion process and this is obviously documented in the reports of these performance appraisal interviews. As such, they have an indirect impact on the chances of promotion. Furthermore, the reports of earlier performance appraisal interviews are used as a basis for the current interviews. In case of unsatisfactory performance, the reports of previous performance appraisal interviews are important as well, since they then become part of an extensive file that can lead to the suspension or the discharge of an employee.

\section{ANALYSES}

We now go into a detailed description of how this well-defined preparation influences the way the actual performance appraisal interviews are talked into being on a turn-by-turn basis. Using the exemplary nature of the extracts as a criterion for selection, we selected a number of typical fragments from the entire corpus for further in-depth analysis. In particular, we focus on excerpts in which topics are initiated by the interviewer since these are most 
insightful for the focus of this article, namely demonstrating how the questionnaires are made relevant in the interactional construction of the performance appraisal interview. We then discuss how these topics are dealt with against the backdrop of the preparatory work of the pre-interviewing phase. This section is divided into a number of subsections which immediately draw attention to the main point of the upcoming analyses.

\section{Structuring and segmenting the discussion}

First of all, the interlocutors' preparations clearly have a structuring function during the interview and it helps them to align with one another. Furthermore, it also helps the interviewer to break down big and sometimes abstract notions into several themes which all represent different aspects of an umbrella term. An example of this can be seen in the following excerpt.

\section{Excerpt 1 (interview 3) ${ }^{\mathrm{iii}}$}

1 IR De stressbestendigheid, ja we gaan weer bij de grappige dingen kommen,

2 ich vroag mich- ich ben mich aant aafvroagen of ich dat ( )

3 ich zal het waal eens ergens anders onder scharren naderhand maar @

4 IE Stressbestendigheid denk ich dat se onder flexibiliteit mos scharen, neet?

5 IR Joa, joa. Eu:::hm. Ich hou doa de vroagen één tot en met veer

$6 \quad$ aangekoppeld ${ }^{\circ}(\quad)^{\circ}$

$7 \quad(3.0)$

8 IE Van de overige vragen één tot en met veer?

9 IR Nee. @@@ Ein. Der is momenteel veel veel dynamiek in de X,

10 waaronder op onze eigen afdeling, ooch in het verleden hè, 

wat deed dat met dich?

12 IE Ja eigenlijk neet echt, ja ich zeg al: het is zeker spannend maar ich word er zelf persoonlijk neet echt onzeker van.

1 IR The stress immunity, yes we are getting to the funny things again,

$2 \quad$ I ask myself-I am wondering whether I ( )

$3 \quad$ I will put it somewhere else in due course but @

4 IE Stress immunity I think that you must put it under flexibility, no?

5 IR Yes, yes. E:::rm. I had linked the questions one through four

6 to that ${ }^{\circ}()^{\circ}$

$7 \quad(3.0)$

$8 \quad I E \quad$ Of the other questions one through four?

9 IR No.@@@One. At the moment, there is a lot a lot of dynamics in the X,

10 under which on our own department, also in the past hey,

$11 \quad$ what did that do to you?

12 IE Yes actually not really, yes I already said: it is certainly exciting

13 but I myself personally do not become really insecure of it.

In this fragment, the topic of stress immunity is introduced. This is of course related to many different factors within the company, the department and the team, as well as the personality traits and the personal situation of the interviewee. This multi-facetedness of the topic is also demonstrated from an emic perspective, since the interlocutors first discuss the difficulty of categorizing this topic within the overarching themes of the interview (lines 1-3) and an alternative categorization is proposed by the interviewee (line 4). The interviewer then explains how she intends to discuss all the different facets of the topic, namely by linking it to 
four different questions (lines 5-6). The lengthy pause (line 7), the interviewee's question probing for the exact questions on the questionnaire (line 8) and the negative response to this question, which is immediately mitigated by the interviewer's laughter (line 9), all indicate that this information is new to the interviewee. In order to disambiguate the matter, the interviewer then explicitly voices the number of the question (line 9: One) as well as the question itself, which is read out loud in lines 9-11. The question is then answered in the subsequent line, but as the interviewee immediately indicates by framing her answer as a repetition (line 12: I already said), this topic was already discussed before.

Such overlap in the discussion of the topics occurs quite a lot in the interviews, thus showing that the segmentation of these topics can be problematic at times. The following excerpt gives an example of such an overlapping topic:

\section{Excerpt 2 (interview 2)}

1 IR Informatiestroom? Eu:::h, ja vorige kier, has du net aangegoven

2 dat se het veul vinds hè, mededelingen, e-mail, veranderin[gen,

$3 \quad$ IE

[ja ja ja

4 IR werkover[leg ( )

5 IE [Ja heb ich al gezegd.

6 IR Ja goed, ich han ook gezèt: ' $t$ zal nooit meer veranderen.

1 IR Information flow? E:::rm, yes last time, you have just indicated

2 that you think it is a lot hey, announcements, e-mails, chan[ges,

$3 \quad I E$

[yes yes yes

$4 \quad I R \quad$ dicussion of pro[gress ( ) 
6 IR Yes good, I have also said: it will never change again.

Right after the introduction of the topic in line 1 and an extended hesitation, which makes sure the speaker maintains floor holding rights, the interviewer answers the question herself before the interviewee has a chance to gain the floor and she immediately frames it as a repetition of previously discussed issues (line 1: you have just indicated...). In overlap, the interviewee corroborates the interviewer's formulation of her own answer (line 3) and explicitly voices that she has already said all that (line 5). As such, topic closure is initiated and this is corroborated by the interviewer, who finalizes the topic closure by repeating her own response to the previously voiced answer (line 6). Thus in this fragment, the interviewer mainly replays the preceding interaction. As such, she on the one hand makes sure she has explicitly discussed all the different topics on the agenda, but on the other hand she also displays her knowledge of the fact that the answer was already given previously, thus recipient designing her question. This type of recipient design is explained by HoutkoopSteenstra (2000) regarding the topic of standardized survey interviews, in which interviewers can either stick to the rules of standardized interviewing, which, in cases of overlapping topics, often leads to many delays and hesitations on the part of the respondents (2000, p.75), or they can orient to general conversationalist norms and adjust their questions. One way of adjusting the question is seen here, namely "asking a question and then providing its answer", which is described by Houtkoop-Steenstra as "a device interviewers use to solve the interactional problems caused by their recipients' orientation toward ordinary conversation" (2000, p.76). Given the fact that the rules of performance appraisal interviews are not as strict as those of standardized survey interviews, it is not so surprising that the interviewer recipient designs her questions, but rather that she still asks the question in the first place, which thus 
demonstrates her strong orientation to her "institutional identity" of interviewer (HoutkoopSteenstra, 2000, p.86).

So on the one hand, having such an explicit agenda which is dealt with chronologically helps to structure the discussion and segment it into graspable chunks, but on the other hand, this segmentation also leads to substantial topic overlap. This results in many repetitions and the need to recipient design the questions.

\section{Encouraging detailed introspection}

Throughout the interviews, we observed that the high level of detail of the questions invites the employees to reflect on their jobs in an in-depth way and it helps them to discover aspects of the importance of their jobs which they had not thought of before, thus giving them a sense of pride of their work. The following fragment, which is broken down into two excerpts (3A and 3B), gives a good example of this:

Excerpt 3A (interview 2)

1 IR Euhm wat zou er zou er anders moeten?

$2 \quad$ En wo kens se zelf invloed uitoefenen?

$3 \quad(6.0)$

4 IE Doa heb ich mich neet euver bedacht.

5 Ich dacht dat dat wor, bie overige vragen.

6 IR Ok.

$7 \quad(2.0)$

8 IE ${ }^{\circ} \mathrm{Ja}$ joa dat weit ich neet. ${ }^{\circ \circ}$ ( ) Een invloed,

9 dat zou ich ooch neet weiten. Dat is minimaal denk ich, ozze invloed. 
10 IR Ja [nou

11 IE [Mien persoonlijke invloed is zo groot.

1 IR Erm what should be should be different?

$2 \quad$ And where can you have an influence yourself?

$3 \quad(6.0)$

4 IE I have not thought about that.

$5 \quad$ I thought that that was, at other questions.

6 IR Okay.

7

8 IE ${ }^{\circ} Y e s$ yès I don't know that ${ }^{\circ \circ}$ ( ) An influence,

9 I would also not know that. That is minimal I think, our influence.

10 IR Yes [well

11 IE [My personal influence is this big.

The interviewer introduces a new twofold topic, which focuses on what should be different (line 1) and where the interviewee can have an influence (line 2), which is a clearly agendabased question as the and-prefacing highlights (Heritage \& Sorjonen, 1994, p.24). In spite of this agenda-based nature, the questions seem to come as a surprise to the interviewee, as the lengthy pause in line 3 , the explicit negation of previous reflection in line 4 and the account in line 5 for this lack of reflection, which the interviewee relates to the structure of the questionnaire, all indicate. The interviewer acknowledges this account in line 6 , but as the subsequent lengthy pause in line 7 indicates, she leaves the floor open for the interviewee to self-select again and answer the question. This pause is also oriented to by the interviewee in a similar way, because she explicitly acknowledges her lack of an answer in line 8 and she 
implicitly marks this answer as dispreferred by means of the low volume of the delivery. She continues by muttering something unintelligible and by rephrasing this dispreferred response. She then concludes her turn by voicing a response that is hedged by means of the "plausibility shield” I think (Prince et al., 1982, p.90), which minimizes “the degree of the speaker's commitment to the truth-value of the whole proposition" (Markkanen \& Schröder, 1997, p.5). Furthermore, she introduces a collective perspective to the answer, as the $1^{\text {st }}$ person plural possessive form our indicates, but this is quickly, and in overlap with the interviewer's response in line 10 , self-repaired in line 11 , in which the personal perspective of the interviewee's response is emphasized, both by means of the lexical combination of the $1^{\text {st }}$ person singular possessive form my with the adjective personal and by means of the stress which falls on the first syllable of personal thus accentuating it. Furthermore, the hedged nature of the previous statement is repaired and replaced by a factual statement in which the minimal amount of the interviewee's influence is asserted again. So in this excerpt, the interviewee responds negatively, thus expressing quite a low self-esteem regarding her position within the organisation.

However, the interviewer does not simply accept her negative response, and in the following 17 lines she discusses what could be meant by the concept of influence within the professional practice of the interviewee. This is corroborated by the IE by means of latchedon or overlapping affirmative particles. The interviewer then closes this discussion in lines 29-30:

Excerpt 3B (interview 2)

29 IR Ja kiek dat is wat ich bedoel euh euh ja dat is get wo men zelf invloed op ken oetoefenen. 
31 IE Joa ma ja goed, dat vind ich $\downarrow$ ja. Dat is euh $\downarrow$ ja.

32 Dat dat doon ich, £denk ich£.

33

34 IE Dus ich denk, a a als ich noa michzelf kiek denk ich dat ich

35 dat ich doa eigenlijk weinig verandering in ken $\uparrow$ zeen.

36 IR Mmm.

37 IE Dat het nog neet, als eederein het zo zou doon, wor het good.

38 IR Ja ja.

39 IE@ @ Ja de kens dichzelf effe een vèr opstèken

40 maar dan denk ich dat is zo.

41 IR Nè maar goed.

29 IR Yes look that is what I mean erm erm yes that is where one

$30 \quad$ can have an influence oneself.

31 IE Yès, but yes okay, I think that $\downarrow$ yes. That is erm $\downarrow$ yes.

32 I do that that, $£$ I thinkf.

$33 \quad(2.0)$

34 IE So I think, $i$ i if I look at myself I think that I

35 that I can actually $\uparrow$ see little change in that.

36 IR Mmm.

37 IE That it not yet, if everyone would do it like that, it were good.

38 IR Yes yes.

39IE@@ @es you can put a feather on your own cap for a bit

$40 \quad$ but then I think it is like that.

41 IR Nò but good. 
As a response to the interviewer's concluding statement, the interviewee hesitantly affirms this by means of affirmative particles (line 31) and then asserts that she does what the interviewer listed as important for having an influence in the organization. She mitigates this assertion by means of another plausibility shield I think, which is pronounced in a smile voice, which can be defined as words spoken with "a markedly higher pitch and an intonational contour comparable to laughing during speaking but without any laughter tokens"(Buttny, 2001, p.317). Then there is a pause and the interviewee self-selects to add another strongly hedged (line 34: 2x I think, line 35: actually) statement in which she reflects on her own behavior in terms of change, thus shifting back to the first question that was voiced by the interviewer in line 1 . After a continuer by the interviewer, the interviewee then explicitly evaluates her own behavior as very positive in comparison to that of others in the organization (line 37). This positive self-assessment is first corroborated by the interviewer in the next turn by means of two affirmative particles (line 38) and then mitigated by the interviewee herself by means of laughter, an implicit apology by explicitly framing it as a self-oriented compliment (line 39) and a mitigation of the truth value of her statement again by means of the addition of I think (line 40). The interviewer then closes the topic, and, by means of the initial negative particle, she negates the problematic nature of this self-oriented compliment.

So this fragment (excerpts $3 \mathrm{~A}$ and $3 \mathrm{~B}$ ) illustrated that by introducing such detailed topics in the performance appraisal interviews, the interviewees are invited to look at their jobs from a wider, institutional perspective which they are obviously not used to, as the initial negative self-assessments of the interviewee in excerpt 3A illustrates. By explicitly orienting the interviewees' focus to this perspective and by providing a description of how their jobs function in the organizational machinery, they are able to gain insight into this process and see the importance of their contribution (excerpt 3B), even though this was initially described 
as minimal. The performance appraisal interview is thus used here to raise the employees' awareness of the significance of their position within the organisation.

\section{Dealing with lexical complexity in the organisation's competencies}

However, such a consciousness-raising process as described above, is time consuming, since it elicits numerous misunderstandings, questions for further explanation and responses that are off-topic. A term that typically leads to such interactional troubles in our data is collaborating process consciously. Crucially, this is one of the four basic competencies of the organisation (see data description), but in spite of this, it causes a lot of problems. This is also clear from an emic perspective, since the term is immediately marked as problematic by the interviewer herself, as can be seen in the following excerpt.

\section{Excerpt 4 (interview 1)}

1 IR Euh. Procesbewust samenwerken. Vind ich zelf een hele

2 moeilijke. (.) Eu::h ja procesbewust samenwerken is meer dan

3 eu:h alleen maar (.) dien stukje openkleppen op een ( ） stukje hè.

4 Dus verder kieken dan dat ene. Hoe ziet

$5 \quad$ procesbewust samenwerken voor dichzelf oet?

$6 \quad(1.0)$

7 IR Hoe zies se dat veur dichzelf?

$8 \quad(2.2)$

9 IE $\bullet$ h $<$ Procesbewust samenwerken. $>$ (.) Ja hebs het dan hie euver

10 allein dit laboratoriu[m of euh?

11 IR [Nèè:, ken er buiten het laboratorium zeen, 
12 ken in de verplegerafdelingen zien. Wat is dien actieve rol doa in?

13 Wie zies du dien rol doa in?

$14 \quad(3.4)$

15 IE $\quad \cdot h h$ Pfff:::.:.:.:.:.:.::

16

17 IE ${ }^{\circ} \mathrm{Ja}$ hoe mot ich dat zeggen. ${ }^{\circ}(($ rest of the answer omitted $))$

1 IR Erm. Collaborating process consciously. I myself think ((that is)) a very

2 difficult one (.) E::rm yes collaborating process consciously is more than

3 e:rm just (.) open your little piece on a ( ) little piece hey.

$4 \quad$ So look further than that single one. What does

$5 \quad$ collaborating process consciously look like for yourself?

$6 \quad(1.0)$

$7 \quad$ IR How do you see that for yourself?

$8 \quad(2.2)$

9 IE $\quad \cdot h<$ Collaborating process consciously.> (.) Yes are you talking about

$10 \quad$ this lab only her[e or erm?

11 IR [Nò:, it can be outside of the lab,

12 it can be in the nurse's departments. What is your active role in that?

$13 \quad$ How do you see your role in that?

$14 \quad(3.4)$

15 IE $\quad$ hh Pfff:............:

$16 \quad(2.1)$

17 IE $\quad{ }^{\circ}$ Yes how shall I put that.$^{\circ}(($ rest of the answer omitted $))$ 
In the beginning of this excerpt, the interviewer introduces the topic of collaborating process consciously by an extended question consisting of several question components. After the topic is initiated, she immediately shifts to a personal footing and marks the problematic nature of the term (line 1-2), thus constructing her role as the mere 'relayer' of questions (Houtkoop-Steenstra, 2000, pp.45-47). After a brief pause, she self-selects to provide a definition of this term, which is rendered in a slightly hesitant way, as the hesitations (lines 2 and 3) and the additional pause (line 3) indicate. She ends this definition by formulating an explicit question in which she directly addresses the interviewee and invites her to talk about this topic from a personal perspective (line 5). As the interviewee does not ratify this otherselection, there is a brief pause (line 6) and the interviewer then self-selects again and rephrases her question but still addresses it directly to the interviewee. After another lengthy pause (line 8), the interviewee breathes in audibly and repeats the term in a slow, emphatic way. After another brief pause she continues by countering the interviewer's repeated question with another question which probes for a definition of the scope of the question. As such, she passes the turn back to the interviewer, who starts her answer in overlap with the interviewee's question. In this answer, she corrects the interviewee's tentative assumptions about the scope of the term and provides further explanations (lines 11-12). She ends her turn by rephrasing her question twice (lines 12-13), this time orienting it even further to the interviewee's personal involvement. Again, there is a lengthy pause and then the interviewee voices an audible in-breath and a lengthy out-breath, which is again followed by a pause until, finally, the interviewee starts her answer, which she prefaces by a soft-spoken hesitation about the way to formulate her answer. The actual answer is not reproduced here for reasons of length, but it was off-topic and needed to be corrected by the interviewer again, which is quite unsurprising given the preceding turns. On the one hand, the interviewee's lengthy pauses, hesitations and prosodically marked contributions definitely suggested upcoming trouble (i.e. 
the off-topic response), but on the other hand, the interviewer's formulation of the question with its many explanations and paraphrases is also quite telling. Such elaborate questions have been studied by Puchta and Potter (1999) in a focus group setting which is typically characterized by the institutional representative's dilemma to have the interlocutors focus on a specific topic while at the same time have them talk as spontaneously as possible (1999, p. 315). From this perspective, focus groups and performance appraisal interviews are relatively similar, and thus the three main pragmatic functions of elaborate questions, as identified by Puchta and Potter, are relevant here as well. These functions are: (1) guiding responses and heading off trouble, (2) securing participation by providing participants with an array of alternative items to respond to, and (3) providing guidance in producing the kinds of responses that are appropriate in their particular contexts (Puchta \& Potter, 1999, p.332). As such, these elaborate questions can also be viewed as a form of recipient design here, since they are oriented to helping the interviewee formulate an answer and they demonstrate the interviewer's awareness of the difficulty of the question and of this term in particular. Throughout the three interviews, a significant amount of time is spent on explaining and disambiguating such technical terms, which are obviously not yet familiar to the interlocutors, sometimes even including the interviewer. So we have to conclude that by means of the questionnaire, opaque terminology is sometimes brought into the interview and much interactional effort is required to disambiguate this.

\section{The didactic function of performance appraisal interviews}

As the previous example also demonstrated, the interviewer sometimes engages in quite lengthy explanations before an answer can be formulated. In certain cases however, the contributions of the interviewee are very limited when compared to that of the interviewer. This happens quite often, sometimes even to such an extent that the collaborative construction 
of meaning is replaced by a one way transfer of information from the interviewer to the interviewee. In such cases, the focus moves away from a personally oriented discussion of the interviewee's professional experiences, and it is redirected to more general - and sometimes even abstract - topics related to the characteristics of the organization, as in the following fragment.

\section{Excerpt 5 (interview 1)}

1 IR De visie? Wat zou volgens dich os gezamelijke visie motten $\downarrow$ zeen?

2 IE Ja ich ich, want, ich ich hub doa zoe een bitje met geworsteld.

3 De visie en de doelen dat ligt toch heel kort bie ijn?

4 IR Nee een visie zagen ze, een visie is eigenlijk een euh, uh, een under

5 een understatement wa wa wat ze eigenlijk als organisatie maaks

$6 \quad$ waarbij se als als organisatie herkenbaar bes voor de hele buitenwereld

$7 \quad(0.8)$

8 IR En dat is vaak, zou het geformaliseerd motten wèren in ein zin

9 waarbij de medewerker die zoe mot kennen opnoemen.

10 IE Wat de visie is van het lab?

11 IR Ja, wat wat, de visie (.) van in dit geval (.) de orfganisatie£ ${ }^{\circ} @{ }^{\circ}$

12

13 IE Een voorbeeld te [zeen, [voorbeeldziekenhuis [euh te zeen, [voor (.)

14 IR $[\mathrm{Ja} \quad[\mathrm{ja}$ [ja: $[\mathrm{ja}$

15 IE $\mathrm{Ne}[$ derland.

16 IR [Euh 't wordt belangrijk, nu in de nieuwbouw,

17 patiëntcentraal. Doa woren we uniek in.

18 IE $\uparrow$ Ja. Omdat dus [deu:h artsen [naar de patiënt [komen (.) ja. 
19 IR

$[\mathrm{Ja}$

[ja

[ja

20 IR Precies ja.

$1 \quad$ IR The vision? What should be our common vision according to $\downarrow$ you?

2 IE Yes, I I, because, I I have struggled a bit with that.

$3 \quad$ The vision and the goals that is yet very close to one another?

4 IR No a vision they say, a vision is actually a erm, erm, an under

5

an understatement ${ }^{\text {iv }}$ what what what actually makes you as an organization

6

with which you as as organization are recognizable for the entire outside world

7

8 IR And that is often, it should be formalized in one sentence

$9 \quad$ with which the employee should be able to name it just like that.

10 IE What the vision of the lab is?

11IRYYes, what what, the vision (.) of in this case (.) the or£ganization£ ${ }^{\circ} @{ }^{\circ}$

12

13 IE To be an ex[ample, [to be erm an[exemplary hospital, [for (.)

$14 I R$

[Yes [yes

[yes:

[yes

15 IE the Ne[therlands.

16 IR [Erm it becomes important, now in the new housing development,

17 patient central. In that we become unique.

18 IE $\uparrow$ Yes. Because thus [the:rm doctors [come to the [patient (.) yes.

$19 I R$

[Yes

[yes

[yes

20 IR Precisely yes. 
In this fragment, the interlocutors discuss the vision of the organization. In the introductory question in line 1 , the interviewer reframes the general question to a personally oriented request to the interviewee to voice her opinion about the organization's vision. The interviewee then immediately hesitantly admits her problems with the topic in line 2 and then defines these problems as a terminological issue by questioning the difference between vision and goals (line 3). In the subsequent turn, the interviewer explicitly rejects this, as the negative particle in line 4 indicates and then starts defining the term. By not only framing this definition as hearsay, but also attributing it to a vague third person plural form (line 4: they say), the interviewer creates a distance between herself and the content of her words by limiting her contribution to that of an animator in Goffman's terms (1981). The many hedges (e.g. repeated use of actually in lines 4 and 5), hesitations (line 4), reformulations (line 4-5, 5 6) and the vague formulations (e.g. the unclear use of the word understatement in line 5) suggest the difficulty the interviewer has in formulating a clear definition. After a brief pause, she self-selects again and continues this definition, as the and-prefacing, which establishes a sequential character here (Neville, 2006), indicates. This initial continuation has a descriptive nature (line 8: that is often), but the descriptive tone then shifts to a normative formulation, as the use of the modal verbs of obligation in lines 8 and 9 indicates. Interestingly, this normative formulation does not explicitly address the interviewee, but rather the category of which the interviewee is a part (line 9: employee) and it gives hints as to the - intonationally stressed - linguistic form of this vision (line 8: one sentence). The interviewee responds with another question, and the interviewer initially confirms. Then she shifts to a repair of the institutional scope of the vision (the organization (line 11) versus the lab (line 10)). This correction is pronounced by using a smile voice and is followed by soft laughter which mitigates the face threatening nature of this correction. After another quite lengthy pause, the interviewee finally answers the question and this answer is immediately confirmed by the 
interviewer by means of four repeated affirmative particles which overlap the interviewee's formulation and reformulation of her answer. Before she can finish her answer (line 15), the interviewer overlaps again by adding another aspect of the organization's vision, namely patient centrality (line 17). Before and after voicing this term, the interviewer stresses the importance of this aspect for the future (line 16: it becomes important, line 17: we become unique). The interviewee corroborates the importance of this aspect and elaborates on it by means of a causal subordinate clause which explains the term the interviewer has just added to the interviewee's description of the organization's vision. This addition is then confirmed by the interviewer by overlapping affirmative particles and by closing the topic by means of a boosted confirmation (line 20).

So in this fragment, we see an important focus on terminological explanations and transfer of information from the interviewer to the interviewee regarding a topic in which the interviewee's involvement is not stressed at all, but which is dealt with in a relatively abstract and theoretical way. In this fragment, the three-part sequence (initiation, response, feedback) typical of classroom interaction as described by Sinclair and Brazil (1982), can be identified, giving this interaction a truly didactic appearance and reducing the role of the interviewee to that of a student who is questioned about her knowledge of the organization. This highlights the power asymmetry that can be talked into being in such interviews, with interviewees trying to come up with an answer that is correct, in the sense that it is in line with institutional norms and expectations and anticipating on what the supervisor wants to hear (cf Wasson, 2000).

In this case, the response is constructed in a collaborative way, but there are also a number of fragments in which there is no response from the interviewee and we can only observe one way, top down, communication that is maintained throughout the entire discussion, as the final fragment illustrates. 
Excerpt 6 (interview 2)

1 IR En euh, ja de aantal doelen die kens se waal zoe euh standaard

2 benoemen denk ich veur de veur de hie veur de afdeling zelf.

$3 \quad(1.1)$

4 IR Wat is, wat is, wat is voor os, voor uch maar auch voor os heel belangrijk?

5

6 IE ${ }^{\circ} \mathrm{Ja}:{ }^{\circ}$

7 IR En wo we auch hiel lang over zeuren. ${ }^{\circ}{ }^{\circ}$

8 IE Ja det weit ich neet ((first name)). Precies.

9 IR De TAT's, turn-around-tijden hè.

10 IE Oh ja ja ja ja::.

11 IR Het cito-be $\downarrow$ leid, de wacht $\downarrow$ lijsten, de klinische bloedaf $\downarrow$ name=

12 IE $=\bullet$ h Ja ja::=

13 IR $=$ cyber $\downarrow$ track

$14 \quad($.

15 IR >dat is dat dat systeem van de bloedtransfusie wo wer met bezig zeun<

16 IE ${ }^{\circ} \mathrm{Ah}$ ja dat dat wist ich neet. ${ }^{\circ}$

1 IR And erm, yes the number of goals you can name them erm in a standard way

$2 \quad$ just like that I think for the for the here for the department itself.

$3 \quad(1.1)$

4 IR What is, what is, what is for us, for you but also for us very important?

5 
$6 \quad I E \quad{ }^{\circ} Y e:: s^{\circ}$

7 IR And about what we've also been nagging about for a very long time. ${ }^{\circ}{ }^{\circ}$

8 IE Yes I don't know that ((first name)). Exactly.

9 IR The TAT's, turn-around-times hey.

10 IE Oh yes yes yes ye:::s.

11 IR The cito-po $\downarrow$ licy, the waiting $\downarrow$ lists, the clinical blood col $\downarrow$ lection $=$

12 IE $=\bullet h$ Yes ye::s=

13 IR $=$ cyber $\downarrow$ track

$14 \quad($.

15 IR >that is that that system of the blood transfusion with which we are busy<

16 IE ${ }^{\circ}$ Ah yes that that I didn't know. ${ }^{\circ}$

In the first line, the interviewer introduces the topic of the goals of the company. Interestingly, instead of asking the interviewee in a straightforward way what the goals are, she asserts, in a tentative way (cf the plausibility shield I think in line 2), that the interviewee is able to name them. As such, she downplays the difficulty of the question, which is further achieved by the hedges in a standard way and just like that. By this tentative assertion, she implicitly invites the interviewee to name the goals. Similar to the pattern in the previous fragments, there is a lengthy pause, after which the interviewer reformulates this assertion into a question and directly addresses the interviewee as a member of the organization (line 4: for you but also for $u s)$. Again, a lengthy pause follows and then the interviewee utters a softly spoken affirmative particle, of which the lengthening suggests hesitation. The interviewer then provides a further hint about the answer, which is threatening her own positive face (Brown \& Levinson, 1987) since it suggests that she is a complainer, but this is quickly mitigated by a short laugh. Interestingly, these hints and paraphrases are of decreasing technicality, thus lowering the 
threshold for the interviewee. The interviewee then explicitly states her lack of knowledge, which she then mitigates by limiting its scope to the insufficiency of her knowledge concerning its level of detail (line 8: exactly). The interviewer then starts a list, which is prosodically marked as such by its repeated falling intonation, listing the topics about which

goals have been formulated in lines 9, 11 and 13. The interviewee confirms these by means of affirmative particles, and when she does not corroborate an item on the list, as in line 14, the interviewer provides a definition of the term, after which the interviewee again acknowledges her understanding.

So in this fragment, there is a clear orientation to the transfer of information and the role of the employee is limited to that of a passive, one could even say powerless, recipient of this relatively general, abstract knowledge. Furthermore, given the fact that the interviewee's understanding is checked, as the additional explanation in line 15 illustrates, this interaction has a didactic nature and the interviewer is clearly oriented to conveying technical information and transmitting the management line to the interviewee rather than discussing what this entails for the functioning of the employee in the organization. Moreover, since this is not dealt with in the turns following this excerpt, which are omitted here for reasons of length, there almost seems to have been a genre shift from a performance appraisal interview to a didactic interaction. Since there are plenty of other examples of such a genre shift in our data, this seems to be a hidden function of performance appraisal interviews in which the asymmetry in knowledge between the interviewer as a supervisor and the interviewee as a subordinate is talked into being.

\section{DISCUSSION, CONCLUSIONS AND PRACTICAL IMPLICATIONS}

The organization in which we collected our data has a well thought-out way of dealing with the performance appraisal interviewing process, which is closely linked to the organizational 
competencies and which is defined in clearly discernable steps, as we have shown in the data description. So in theory, this organization could be characterized as highly professional in its way of doing performance appraisal. However, this article set out to explore the potential gap between theory and what really goes on in institutional practice. As the discussion of the selected excerpts illustrated, in real life the picture is quite nuanced, entailing a number of both positive and negative effects of this type of preparatory process, which we sum up here.

- On the positive side, we can conclude that:

1. the interviews contain a diversity of topics which incites the employees to reflect profoundly on obvious, but also less obvious aspects of their jobs (see e.g. excerpt 3A and 3B) and since these topics are based on the four competencies of the organization, this possibly urges the employees to internalize these competencies and the interview process may help them to put these skills into practice in their daily work routine;

2. the use of a well-defined agenda that is identified a long time before the actual interview has a structuring function, especially since it helps the interlocutors to break down abstract notions into smaller, graspable chunks (see e.g. excerpt 1).

- On the negative side, we can conclude that:

1. the whole process, both regarding preparatory and interviewing time, seems very time consuming, and this is also confirmed in the ethnographic interview ${ }^{\mathrm{v}}$;

2. the focus is sometimes quite strongly on the transfer of information and it is particularly at these points that the employees' role is reduced to that of a passive recipient to whom information, but also institutional norms and expectations, are transferred (see e.g. excerpt 5, and also 6);

3. the terminology is sometimes needlessly difficult, which also entails a lot of local explanatory work and terminological disambiguation (see e.g. excerpt 4); 
4. the amount of the employees' participation in the interaction fluctuates and this seems causally related to the orientation of the talk. This orientation sometimes shifts from the personal level to the organizational level (see e.g. excerpt 6) and while the former usually entails high employee involvement, the latter often does not.

This overview demonstrates that a number of critical remarks can be made about the way this organisation goes about doing performance appraisal. The use of the questionnaire may result in wasting precious company time, not only due to the process itself, but also due to additional explanations of technical terminology. So even though we think it is a good idea to work with the four basic competencies of the company as a starting point for the performance appraisal interviews, the analyses have demonstrated that presenting these in 'raw' form may be problematic.

On the one hand, some of these problems could be solved relatively easily by means of a couple of simple measures, such as:

1. using terminology that is accessible to employees at all the different levels of the organization;

2. reflecting on which information could be filtered from the interviews and possibly transferred to other, less time consuming, media such as company websites, inhouse newspapers and training seminars.

On the other hand, many problems are the result of the interactional construction of meaning as it is negotiated by the two interlocutors. For example, the overlapping topics may be partially solved by having a critical look at the different topics and questions that are listed on the questionnaire and by possibly filtering out some questions which are very strongly related to one another. But still, interlocutors will continue to initiate topics that relate to other questions, thus resulting again in overlap. So this is definitely something that cannot be fully anticipated or 'solved' pre-interactionally, but instead it requires an interactional flexibility 
from both interlocutors. The interviewer could have an important role here, since he or she is in charge of asking the questions and thus has the power to skip overlapping topics, thus initiating a shift in the participants' orientation towards the norms of ordinary conversation instead of to the rules of interviewing on the basis of a pre-defined questionnaire, as explained by Houtkoop-Steenstra (2000). Since there are many different elements that potentially influence the ease with which these orientations are negotiated, such as the interviewer's experience with performance appraisal interviews, the formality and quality of the relation between the interlocutors, the interviewee's interactional preferences and so on, it is impossible to give hard and fast rules here. However, we believe that an increased awareness of this potential conflict between the interactional norms of ordinary conversation and those of an institutionally pre-structured interaction on the basis of a questionnaire, can help interlocutors navigate between these sets of norms in order to improve the quality of performance appraisal interviews as they are progressing from one turn to the next.

Of course, these suggestions for improvements are tailored to the needs of the particular line of approach in the organization under study, but they are also more generally applicable for organizations that use similar questionnaires. Furthermore, the advantages of this type of approach should not be forgotten either and so it may also function as an inspiration for organizations using other ways to help their employees and supervisors prepare for performance appraisal interviews. When taking into account all the findings of this article, a critical approach to these questionnaires based on organizational competencies can be implemented that could go some way to anticipating the negative elements listed above. As such, our findings not only provided an in-depth view on the effect of using this specific type of questionnaire on the actual performance appraisal interview, thus contributing to bridging the gap between theory and practice, but they also offered a number of insights into the performance appraisal process. Moreover, even though these findings are based on data from 
a single organization, and it is hoped that further research in other organizational contexts will add to and complement the findings of this paper, they contain useful information that has a wider applicability and that could result in improvements to, or a more successful implementation of, performance appraisal interviews in organizations. Finally, we hope that these findings from the analysis of actual performance appraisal interviews may feed back into the advisory literature on this institutional genre, and in particular on how questionnaires can be dealt with in an efficient way in these interviews, as such supporting the formulation of more nuanced "stocks of interactional knowledge" (Peräkylä \& Vehviläinen, 2003) that are based on the terra firma of real life institutional practice (see also Clifton, forthcoming).

\section{APPENDICES}

\section{*** SEE DOCUMENT ENTITLED ‘table_appendix’***}

\section{REFERENCES}

Asmuß, B. (2008). Performance appraisal interviews: Preference organization in assessment sequences. Journal of Business Communication, 45(4), 408-429.

Broekhuis, M. \& Holthuis, M. (2004). Haal meer uit het functioneringsgesprek met uw baas. Taalanker (46). Alphen aan den Rijn: Kluwer.

Brown, P. \& Levinson, S.C. (1987). Politeness, some universals in language usage. Cambridge University Press: Cambridge.

Buttny, R. (2001). Therapeutic humor in retelling the clients' tellings. Text, 21(3), 303-327.

Cameron, D. (2000). Good to talk. Living and working in a communication culture. London: Sage. 
Clifton, J. (2006). A conversation analytical approach to business communication: The case of leadership. Journal of Business Communication, 43(3), 202-219.

Clifton, J. (2009). Beyond taxonomies of Influence: "Doing" influence and making decisions in management team meetings. Journal of Business Communication, 46(1), 57-79.

Clifton, J. (forthcoming). Conversation analysis in dialogue with stocks of interactional knowledge: Facework and appraisal interviews. Journal of Business Communication, Prepublished March 8, 2012, DOI: 10.1177/0021943612436974.

Drew, P. \& Heritage, J. (1992). Analyzing talk at work: an introduction. In P. Drew \& J. Heritage (Eds.), Talk at work - Interaction in institutional settings (Studies in Interactional Sociolinguistics 8) (pp. 3-65). Cambridge University Press: Cambridge.

Fletcher, C. (2001). Performance appraisals and management: The developing research agenda. Journal of Occupational and Organisational Psychology, 74, 473-487.

Gioia, D., Donnellon, A., \& Sims, H. (1989). Communication and cognition in appraisal. A tale of two paradigms. Organization Studies, 10, 503-530.

Goffman, E. (1981). Forms of talk. Oxford: Basil Blackwell.

Gordon, M. \& Stewart L. (2009). Conversing about performance. Discursive resources for the appraisal interview. Management Communication Quarterly, 22(3), 473-501.

Grote, D. (2002). The performance appraisal. Question and answer book. A survival guide for managers. New York: Amacom books.

Heritage, J. \& Sorjonen, M.-L. (1994). Constituting and maintaining activities across sequences: and-prefacing as a feature of question design. Language in Society, 23(1), 129.

Holmes, J., Stubbe, M. \& Vine, B. (1999). Construction professional identity: "Doing power" in policy units. In S. Sarangi \& C. Roberts (Eds.), Talk, work and institutional order; 
discourse in medical, mediation and management settings (pp. 351-385). Mouton de Gruyter: Berlin - New York.

Houtkoop-Steenstra, H. (2000). Interaction and the standardized survey interview; The living questionnaire. Cambridge: Cambridge University Press.

Jansen, C., Steehouder, M. \& Gysen, M. (2004). Professioneel communiceren; Taal- en communicatiegids. Groningen: Martinus Nijhoff Uitgevers.

Kikoski, J. \& Litterer, J. (1983). Effective communication in the appraisal interview. Public Personnel Management, 12, 33-42.

Markkanen, R. \& Schröder, H. (1997). Hedging: A challenge for pragmatics and discourse analysis. In R. Markkanen \& H. Schröder (Eds.), Hedging and discourse, approaches to the analysis of a pragmatic phenomenon in academic texts (pp. 3-18). Walter de Gruyter: Berlin / New York.

Neville, M. (2006). Making sequentiality salient:and-prefacing in the talk of airline pilots. Discourse Studies, 8(2), 309-332.

Nielsen, M.F. (2009). Interpretative management in business meetings. Journal of Business Communication, 46(1), 23-56.

Peräkylä, A., \& Vehviläinen, S. (2003). Conversation analysis and the professional stocks of interactional knowledge. Discourse \& Society, 14(6), 727-750.

Poncini, G. (2004). Discursive strategies in multicultural business meetings (Linguistic Insights, Volume 13). Peter Lang: Bern.

Potter, J. (1996). Representing reality; discourse, rhetoric and social construction. Sage: London.

Prince, E.F., Frader, J. \& Bosk, C. (1982). On hedging in physician-physician discourse. In R.J. Di Pietro (Ed.), Linguistics and the Professions (pp. 83-97). Ablex Publishing Corporation: New Jersey. 
Puchta, C. \& Potter, J. (1999). Asking elaborate questions: Focus groups and the management of spontaneity. Journal of Sociolinguistics, 3(3), 314-335.

Rettinger, S. (2011). Construction and display of competence and (professional) identity in coaching interactions. Journal of Business Communication, 48(4), 426-445.

Sinclair, J. \& Brazil, D. (1982). Teacher talk. Oxford: Oxford University Press.

Virkkula-Räisänen, T. (2010). Linguistic repertoires and semiotic resources in interaction. Journal of Business Communication, 47(4), 505-531.

Wasson, C. (2000). Caution and consensus in American business meetings. Pragmatics, $10(4), 457-481$.

\section{NOTES}

\footnotetext{
${ }^{\mathrm{i}}$ All the names and other elements that could lead to recognition of the participants and organization involved have been changed in the transcripts and analysis in order to ensure full anonymity.

ii This term is a literal translation of the Dutch original 'Procesbewust samenwerken'. It could be glossed as awareness of institutional working processes, but this translation would not to do justice to its opaque nature in Dutch. This unintelligibility becomes especially clear in the analysis of excerpt 4, in which we focus on the interlocutors' discussion of the difficulty of this term.

iii An explanation of the transcription symbols can be found in appendix 2 .

iv Although it may seem illogical, the word 'understatement' is a correct translation. As can be seen in the Dutch original, the interviewer uses the exact same word in Dutch, which is illogical in this context as well.
} 


\footnotetext{
${ }^{v}$ Regarding interviewing time, we have to note that we do not base this observation on comparative data that would support the claim that these interviews take longer than interviews without questionnaires. It would also be impossible to make such a comparison in a meaningful way, given the many contextual elements which often strongly influence the interviews' length. However, we base this claim on the fact that topics are often very extensively disambiguated and their meaning is strongly negotiated when they are initiated, rather than when they are discussed. Such disambiguation often takes several turns, as demonstrated, and this is of course quite time consuming and we argue that this could be dealt with in more efficient ways.
} 